ACTA AGROBOTANICA

Vol. 58, z. 12005

s. 2936

\title{
Elements of Integration in Winter Wheat Protection Programs
}

\section{CECYLIA JAŃCZAK ${ }^{1}$, GRAŻYNA FILODA ${ }^{1}$, ROBERT MATYSIAK ${ }^{2}$}

\author{
'Plant Protection Institute, 60318 Poznań, Miczurina 20, Poland \\ e mail: c.janczak@ior.poznan.pl \\ ${ }^{2}$ DuPont Poland \\ Matysiak/EUR/DuPont@DuPont
}

(Received: 15.03.2005)

\section{Summary}

In Poland winter wheat is grown on the area of 1.600 .000 ha. Most of the plant protection treatments are being done without thorough analysis of real threats from pests and diseases. The aim of the research is to develop the optimal program of wheat protection against pests and diseases based on integration of various methods of plant protection. Two programs: conventional and integrated were compared. In integrated program the eventual needs and terms of treatments were estimated on the basis of detailed observations of plant infection, pest appearance, their natural enemies and thorough analysis of weather conditions and forecasts. The role of disease resistant wheat varietes and nitrogen fertilizers was also analysed. The research took into account beneficial entomofauna and its influence on pest numbers as well as influence of chemicals used in agriculture on their species. As the result the selective pesticides, safe to beneficial organisms, were selected. The quantity and quality of winter wheat yield was analysed, including protein and gluten contents. The economic effectiveness of various programs of wheat protection against pests and diseases was assessed. The results of research are important both in practical and scientific sense.

Key words: winter wheat, cultivars, susceptibility, nitrogen fertilization, fungal diseases, fungicides, insecticides, effectiveness of control

\section{INTRODUCTION}

Cereals are grown in Poland on 8,7 millions hectares, of which winter wheat on 1.6 millions hectares, i.e. on about $30 \%$ of cereal acreage. In last ten years acreage of winter wheat considerably increased and it could be expected, that it will still increase due to high profitability of its production. 
The process of plant production intensification has been stopped by economic changes which took place in Poland in the nineties. The very high increase of production costs caused the significant reduction of the use of plant protection products and fertilizers (Mieczkowski and Pruszyński, 2001). This expense cuttings resulted in the yield decrease by $22 \%$ from $32.8 \mathrm{dt} / \mathrm{ha}$ in 1990 to $25.3 \mathrm{dt} / \mathrm{ha}$ in 2000 (Kr a s o w i c z, 2002).

In Poland total use of herbicides and fungicides in terms of active substance amounted to average $0.52 \mathrm{~kg}$ per hectare in the years 1993-1998 and was four times lower than it was in Germany and more than eight times lower as compared to the United Kingdom a country, where the highest cereal yields have been obtained (Figure 1). In the same period also the considerable differences in the use of mineral fertilizers took place. Polish agriculture was characterised mainly by very low use of nitrogen fertilizers (Figure 2).

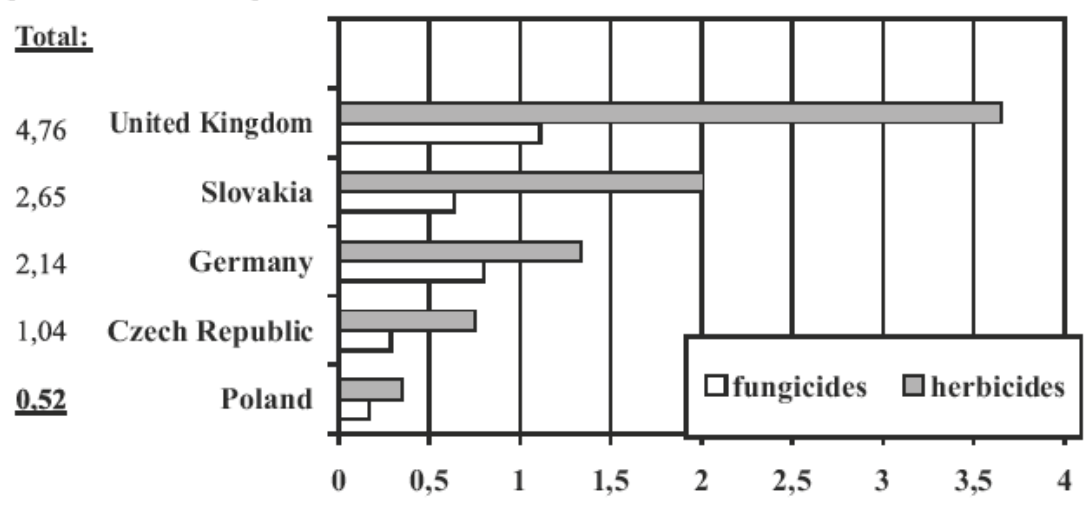

Figure 1. Use of fungicides and herbicides in terms of active substance per one ha of arable crops in 19931998 (according to FAO 2000)

Total:

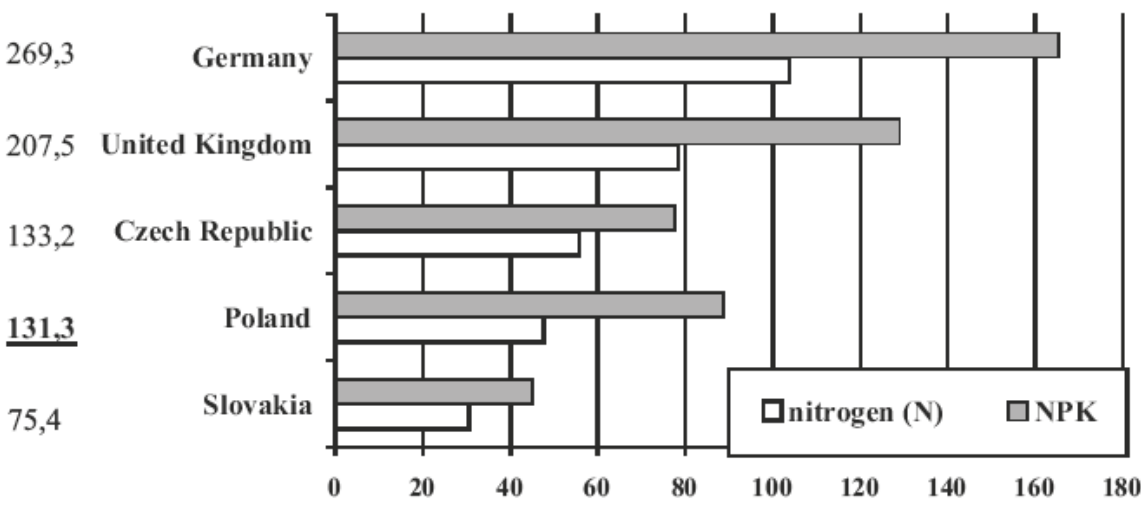

Figure 2. Use of nitrogen (N) and mineral fertilizers (NPK) in $\mathrm{kg}$ per one hectare of arable crops in 19931998 (according to FAO 2000) 


\section{MATERIAL AND METHODS}

Field experiments were carried out in Agricultural Experimental Station of Plant Protection Institute in Winna Góra (Great Poland) in 1999-2000 using the method of randomized blocks on the plots of 16.5 square meters surface in 4 replications on two winter wheat cultivars (Elena and Tercja) having various susceptibility to fungal pathogens. In the experiments two levels of nitrogen fertilization were applied from which the first one was similar to mean fertilization level of winter wheat in Poland $(120 \mathrm{~kg} \mathrm{~N})$, whereas the second one $(170 \mathrm{~kg} \mathrm{~N})$ was recommended as the optimal.

Experimental objects according to the unified method were as follows:

1. untreated without protection against fungal diseases and pests,

2. conventional (traditional) protection two treatments using fungicides were performed in timings similar to those performed commonly on productive fields:

- I against eye spot disease (flusilazol+carbendazim)

- II against the complex of leaf and ear diseases in earing stage (propiconazole+fenpropimorph).

The treatment with insecticide lambda-cyhalothrin against cereal leaf beetles had been applied, when an average number of cereal leaf beetles increased to $1 \quad 1,5$ larvae per one stalk and aphid number to 5 individuals per one ear.

3. integrated protection disease and pest control has been established on the background of detailed risk analysis in each vegetative period (flusilazol+carbendazim, propiconazole+fenpropimorph, azoxystrobin).

More detailed knowledge of beneficial entomofauna allowed to determine its effect on pest numerousness:

- appearance of pests and their natural enemies was observed and the need of treatment was considered

- entomofauna appearance and effect of chemical treatments on various species of beneficial and noxious entomofauna were analysed.

For pest control the selective insecticide Dimilin $25 \mathrm{WP}$ was applied on the background of thresholds of noxiousness.

Fungicides and insecticides applied for winter wheat protection are listed in Table 1. The newest generation fungicides, representing various mechanisms of action on physiological processes of pathogens, were applied in the experiments.

Table 1. List of fungicides and insecticides applied for the control of fungal diseases and pests

\begin{tabular}{|c|c|c|c|c|}
\hline \multirow[b]{2}{*}{ Trade name } & \multicolumn{2}{|c|}{ Active substance } & \multirow[b]{2}{*}{ Chemical group } & \multirow[b]{2}{*}{$\begin{array}{c}\text { Application rate } \\
\text { per one ha }\end{array}$} \\
\hline & Common name & $\begin{array}{l}\text { Amount of active } \\
\text { substance }\end{array}$ & & \\
\hline & $\begin{array}{l}\text { flusilazol } \\
\text { carbendazim }\end{array}$ & $\begin{array}{l}125 \mathrm{~g} \\
250 \mathrm{~g}\end{array}$ & $\begin{array}{l}\text { azoles } \\
\text { benzimidazoles }\end{array}$ & 1,01 \\
\hline & $\begin{array}{l}\text { propiconazole } \\
\text { fenpropimorph }\end{array}$ & $\begin{array}{l}125 \mathrm{~g} \\
300 \mathrm{~g}\end{array}$ & $\begin{array}{l}\text { azoles } \\
\text { morpholines }\end{array}$ & 1,01 \\
\hline $\begin{array}{l}\text { Amistar } 250 \\
\text { SC }\end{array}$ & azoxystrobin & $250 \mathrm{~g}$ & strobilurin analogues & 1,01 \\
\hline $\begin{array}{l}\text { Karate } 25 \mathrm{WG} \\
\text { Dimilin } 25 \mathrm{WP}\end{array}$ & $\begin{array}{l}\text { lambda- } \\
\text { cyhalothrin } \\
\text { diflubenzuron }\end{array}$ & $\begin{array}{l}25 \mathrm{~g} \\
25 \%\end{array}$ & $\begin{array}{l}\text { pyrethroids } \\
\text { benzoylurea } \\
\text { derivatives }\end{array}$ & $\begin{array}{l}0,25 \mathrm{~kg} \\
0,30 \mathrm{~kg}\end{array}$ \\
\hline
\end{tabular}




\section{RESULTS}

The year 2001 was the period of the highest appearance of diseases and their epiphytic development on flag leaves in the stage of water maturity of wheat grain (BBCH-71) on the Elena cultivar (Table 2). In the case of Tercja cultivar the year 2001 was the period of numerous occurrence of cereal leaf beetle larvae on the plants as well as numerous cereal aphid occurrence on the leaves.

- In order to determine the necessary elements of integrated protection as well as timings of disease control the potential risk had been estimated on the background of detailed observations of infection and the analysis of information concerning weather forecasts.

- Different reactions of wheat cultivars to the infection of pathogens as well as effect of two levels of nitrogen fertilization on pest and disease occurrence were evaluated (Table 3).

- Winter wheat yields were analysed taking into account grain size and programmes of winter wheat protection were evaluated from economic point of view.

- Choice of plant protection products, application rates and timings allowed for obtaining high grain yields of good quality as well as economic profitability of production (Table 4).

Table 2. Occurrence of diseases on flag leaf (L1) on untreated plots BBCH $71 \quad$ 04.07.2001

\begin{tabular}{|l|c|c|c|c|}
\hline \multirow{2}{*}{\multicolumn{1}{|c|}{ Diseases (Pathogens) }} & \multicolumn{4}{|c|}{ Average per cent of infected flag leaf L1 surface } \\
\cline { 2 - 5 } & \multicolumn{2}{|c|}{ Elena cultivar } & \multicolumn{2}{c|}{ Tercja cultivar } \\
\cline { 2 - 5 } & $\begin{array}{l}\text { I level of N } \\
\text { fertilization }\end{array}$ & $\begin{array}{c}\text { II level of N } \\
\text { fertilization }\end{array}$ & $\begin{array}{c}\text { I level of N } \\
\text { fertilization }\end{array}$ & $\begin{array}{c}\text { II level of N } \\
\text { fertilization }\end{array}$ \\
\hline $\begin{array}{l}\text { Brown rust } \\
\text { (Puccinia recondita f. sp. tritici } \\
\text { Eriks.) }\end{array}$ & 21,04 & 30,67 & 7,33 & 9,80 \\
\hline $\begin{array}{l}\text { Leaf spot } \\
\text { (Septoria tritici } \text { Rob.ex Desm., } \\
\text { Stagonospora nodorum Berk.) }\end{array}$ & 24,00 & 27,83 & 10,03 & 9,92 \\
\hline $\begin{array}{l}\text { Powdery mildew } \\
\text { (Blumeria graminis DC.) }\end{array}$ & 1,51 & 1,62 & 1,98 & 2,16 \\
\hline
\end{tabular}

In the research carried out on two wheat cultivars and on two levels of nitrogen fertilization several common agrotechnical factors have been separated, being the main elements in the programmes of winter wheat protection as well as in effective technology of wheat production:

- choice of field (proceeding crop, main components of the soil, $\mathrm{pH}$ ),

- seed treatment, optimal sowing period, proper sowing density,

- control of grass- and broadleaved weeds, use of plant growth regulators,

- use of mineral (NPK, Ca, Mg) and foliar fertilizers,

- optimal timing of nitrogen fertilizers 
Table 3. Average infection of two leaves surface on untreated plots

BBCH $51 \quad 20.06 .2001$

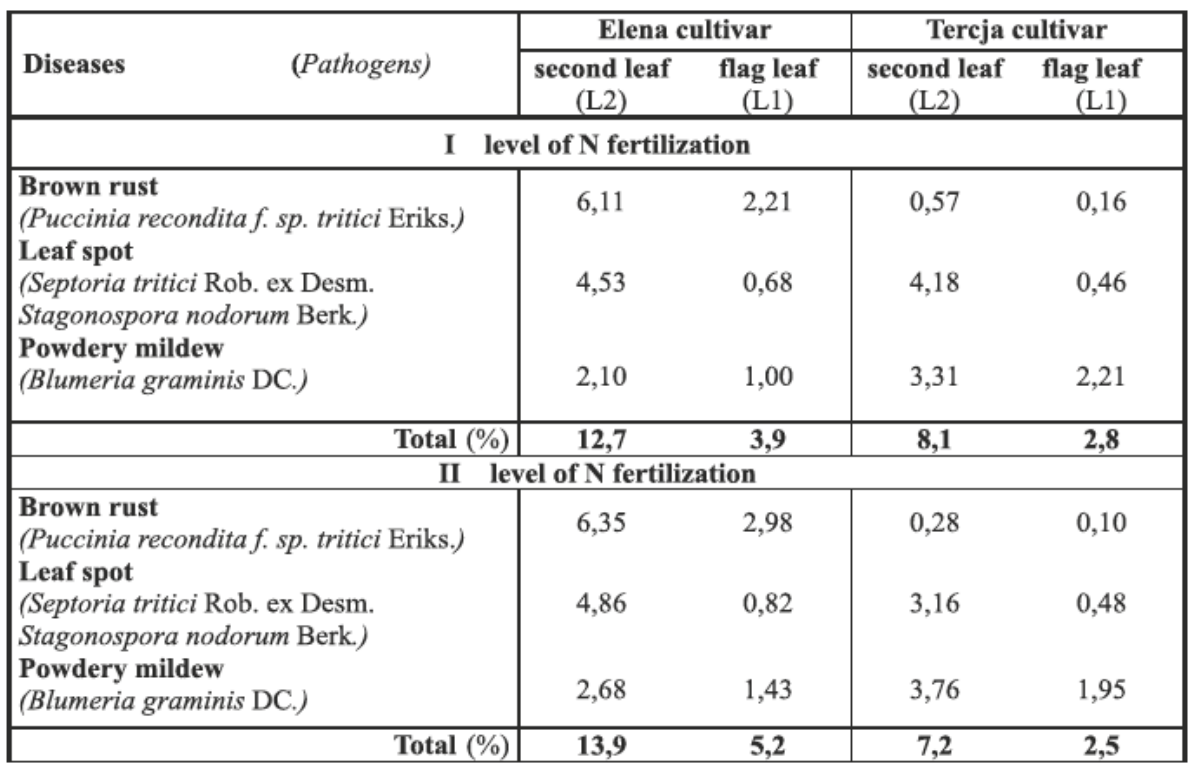

Table 4. Grain yield of two winter wheat cultivars in 2001

\begin{tabular}{|c|c|c|c|c|}
\hline \multirow{2}{*}{ Experiments } & \multirow{2}{*}{$\begin{array}{c}\text { Grain yield } \\
\text { t/ha }\end{array}$} & \multicolumn{2}{|c|}{$\begin{array}{l}\text { Increase as compared to the } \\
\text { untreated }\end{array}$} & \multirow{2}{*}{$\begin{array}{c}\begin{array}{c}\text { Economic } \\
\text { profit }\end{array} \\
\mathrm{zB} / \mathrm{ha} \\
\end{array}$} \\
\hline & & t/ha & $\%$ & \\
\hline \multicolumn{5}{|c|}{ ELENA cultivar } \\
\hline \multicolumn{5}{|c|}{ I level of $\mathbf{N}$ fertilization } \\
\hline Untreated & $5,85 \mathrm{a}$ & - & 100,0 & - \\
\hline Conventional programme & $7,71 \quad$ b & 1,82 & 31,8 & 762 \\
\hline Integrated programme & $8,12 \quad b$ & 2,27 & 38,8 & 712 \\
\hline \multicolumn{5}{|c|}{ II level of $\mathrm{N}$ fertilization } \\
\hline Untreated & $6,45 \quad b$ & - & 100,0 & \\
\hline Conventional programme & $8,63 \quad \mathrm{~b}$ & 2,18 & 33,8 & 858 \\
\hline Integrated programme & $9,06 \mathrm{~b}$ & 2,61 & 40,5 & 796 \\
\hline \multirow{2}{*}{\multicolumn{5}{|c|}{$\begin{aligned} \operatorname{LSD}_{(0,01)} & =0,41 \\
& \text { TERCJA cultivar }\end{aligned}$}} \\
\hline & & tivar & & \\
\hline \multicolumn{5}{|c|}{ I level of $\mathbf{N}$ fertilization } \\
\hline Untreated & $6,06 \mathrm{a}$ & $=$ & 100,0 & $=$ \\
\hline Conventional programme & 7,65 & 1,59 & 26,2 & 624 \\
\hline Integrated programme & 8,07 & 2,05 & 33,2 & 580 \\
\hline \multicolumn{5}{|c|}{ II level of $\mathbf{N}$ fertilization } \\
\hline Untreated & 6,49 a & - & 100,0 & \\
\hline Conventional programme & 8,50 & 2,01 & 31,0 & 756 \\
\hline Integrated programme & 8,79 & 2,30 & 35,4 & 610 \\
\hline
\end{tabular}


I after the start of winter wheat vegetation,

II in the stage of first second node (BBCH 31-32).

- preventive treatments with fungicide against the eye spot diseases (in the stage of first node).

The obtained results revealed also that the decision on the treatment against eyespot diseases first of all should take into consideration the distribution of rainfalls during vegetative season, which can affect significantly the threshold of noxiousness for such the diseases. The example of the effect of water scarcity on the stimulation of pathogen development are the results of trials carried out in 2000. The early spring very low infection of stalks by Tapesia yallundae Wallwork (eyespot) and lack of stalks infected by Fusarium spp. (fusarial stalk rot) showed at the end of April not existing risk of eyespot diseases for both wheat cultivars. In turn, in July it has been stated, that maturating stalks were almost completely infected by Tapesia yallundae Wallwork. Weak development of diseases had been caused by dry soil in May and June 2000. On the other hand, lack of the water in the soil considerably weakened the state of plants. Weak stalks became susceptible to the attack of pathogenic fungus causing eyespot diseases in the situation of heavy rainfalls in the beginning of July.

The research and obtained results have showed that:

- Winter wheat belongs to the cereals of high yield potential and the main factors influencing the yield level are rates and methods of nitrogen fertilizers application as well as the programme of plant protection.

- Chemical protection influences first of all the stability of yield.

- No effect of differentiated protection with fungicides on the rate of technological grain value has been stated.

- Additional application rate of nitrogen fertilizer (about $100 \mathrm{zt} / \mathrm{ha}$ ) had the effect on average yield increase of Elena cultivar by $7.6 \%$ (4,5 dt/ha) and Tercja cultivar by $6.2 \%$ (3.2 dt/ha).

- Control of high intensity pests and diseases allowed to reduce the losses in wheat yield:

for Elena cultivar by $16-40 \%$, for Tercja cultivar by $19-37 \%$.

- The application of the environmental friendly insecticide Dimilin 25 WP enabled the presence of beneficial entomofauna in the programme of integrated protection, nevertheless this insecticide was in fact too selective and thus low effective in the pests control.

The obtained results correspond with literature reports (J áczak et al., 2002 and 2003) and allow to indicate the most important elements of integration:

1. Choice of cultivar high yield and resistant to the diseases occurring in local conditions. The knowledge of phytosanitary conditions of the region of winter wheat cultivation is recommended.

2. Nitrogen fertilization applied at the beginning of earing stage improves the technological grain parameters (protein, glutene) as well as quantity of yield (R o z bic ki, 2000). 
- Additional application of nitrogen fertlizer ,on the ear” was of high importance not only for yield level but also visibly influenced field ,,architecture”.

- Decision on the application of high rates of nitrogen fertilizer should depend on the expected effect on the yields as well as on the relationship between grain price and expenses for nitrogen fertilization.

3. Systematic inspections of the fields regarding the current phytosanitary situation, thresholds of economic noxiousness as well as expected development of pest and disease populations should decide on the need of chemical treatments.

4. Diagnostics and forecasts of risk presented by noxious organisms as well as forecasts of timings and numbers of treatments are significant elements of integration in the programme of winter wheat protection.

1. Results of research show real possibility of implementation of integration elements to conventional programmes of winter wheat protection against diseases and pests.

2. Implementation of the system of integrated protection would enable the more effective use of plant protection products reducing expenses of winter wheat production.

3. Implementation of the system will require proper education both of advisory services and farmers.

\section{REFERENCES}

FAOSTAT, Agriculture: FAO Statistical Databases, Rzym 2000.

Jańczak C., Bubniewicz P., Pruszyński S., 2002. Elementy integracii v zaščite ozi moj pšenicy ot boleznej i vreditelej. Materiały z konferencji na temat: Integrirovannye sistemy zaščity rastenij. Nastojaščee i buduščee. Mińsk, Białoruś, 1517 lipca 2002 r.

Jańczak C., Pruszyński S. 2002. Razrabotka integrirovannoj programmy zaščity ozimoj psenicy pri ponizennom ispolzovanii chimiceskich sredstv zaščity rastennij. Materiały z Międzynarodowego Sympozjum na temat: Integrirovannye sistemy zaščity v selskom chozjajstve. Sozdanie novych agrotechnologij i techniki dlja primenenija sredstv zaščity rastenij s minimalnymi, ekologiceski racionalnymi normami raschoda. Čopak, Węgry, 1720 września 2002 r.

Jańczak C., Pruszyński S., Bubniewicz P., 2002. Winter wheat protection against diseases and pests in conventional programme of crop protection and in integrated pest management, Proceedings of 6 th Conference of European Foundation for Plant Patho logy, Prague, Plant Protect. Vol. 38 Special Issue 1: 221226.

Jańczak C., Bubniewicz P., Pruszyński S. 2003. Uwarunkowania wdrożenia inte growanej ochrony pszenicy ozimej. Prog. Plant Protection/Post. Ochr. Roślin 43(1): 146149.

Jańczak C., Bubniewicz P., Pruszyński S., 2003. Konwencjonalna a zintegrowana ochrona pszenicy ozimej przed chorobami grzybowymi i szkodnikami. Ochrona Ro ślin, $\mathrm{nr} 3: 24$.

Krasowicz S., 2002. Produkcja roślinna na ziemiach polskich w XIX i XX wieku rys historyczny. Pamiętnik Puławski 130/I: 1132. 
Mieczkowski J., Pruszyński S., 2001. Rynek środków ochrony roślin. Rynek środków produkcji i usług dla rolnictwa Ministerstwo Rolnictwa i Rozwoju Wsi, kwiecień 2001: 1520.

Pokacka Z., 1993. Integrowane programy ochrony roślin w badaniach Instytutu Ochrony Roślin na przykładzie upraw zbóż. Mat. XXXII Sesji Nauk. Inst. Ochr. Rośl. Cz. I: 2127.

Rozbicki J., 2000. Kształtowanie wielkości i jakości plonu zbóż. Produkcja i rynek zbóż. Część III: 141158.

\section{Elementy programu integrowanej ochrony pszenicy ozimej}

Streszczenie

Wyniki badań wykonanych w latach 2000 i 2001 wykazały, że podstawowymi czynnikami decydującymi o wysokości plonowania pszenicy ozimej są: agrotechnika uwzględniająca odpowiedni wybór stanowiska, optymalne nawożenie azotowe oraz dobór odmiany dostosowanej do lokalnych warunków klimatycznych. Chemiczna ochrona pszenicy ozimej wpływa przede wszystkim na stabilność plonowania. O potrzebie wykonania zabiegów ochronnych powinny decydować stałe lustracje plantacji z uwzględnieniem aktualnej sytuacji fitosanitarnej, progów szkodliwości i spodziewanego rozwoju populacji agrofagów. 